Jurnal Ilmu Budaya, Vol. 18, No. 1 Agustus Tahun 2021

\title{
MEDIA SOSIAL: PLATFORMISASI DAN BUDAYA KONVERGENSI
}

\author{
Mita Rosaliza ${ }^{1}$, Risdayati $^{2}$, R.Syamsidar ${ }^{3}$ \\ ${ }^{1,2}$ Universitas Riau \\ ${ }^{3}$ Universitas Lancang Kuning \\ ${ }^{1}$ mita.rosaliza@lecturer.unri.ac.id \\ ${ }^{2}$ Risdayati@lecturer.unri.ac.id \\ rajasyamsidar610@gmail.com
}

\begin{abstract}
When new technology is available on various platforms, there are many transfers of knowledge content or even the platform itself as a medium that produces a culture, the result can be convergence, culture becomes more similar, more similar and uniform as a result, or divergence, when culture adopts technology. in a different way that maintains or even accentuates the difference. Johnston and Johal (1999) stated that the internet is a virtual culture by using the dimensions of Hofstede (1980) it can be concluded that internet culture develops and is unified and uniformized. In this case the algorithm plays a role in regulating the flow of culture that will be transferred to users so that it becomes uniform. Marcus and Gould (2000) review selected platforms for transferring convergent cultures, based on an analysis of the recent work by Hofstede (1991). it can be concluded that culture, as revealed by Hofstede's dimension, does indeed affect multiple platforms and has the potential to be the same or monoculture. With discourse analysis supported from digital data from the Tik Tok platform, this article is expected to contribute to the idea that many platforms are used in social media, which can produce new cultures or even reproduce cultures that are uniform and certain.
\end{abstract}

Keywords: Convergence, Culture, Social Media, Tik Tok

\section{Pendahuluan}

Media sosial sebagai salah satu alat komunikasi paling populer di masyarakat kontemporer, digunakan di seluruh dunia dan telah menjadi bagian penting dari kehidupan sehari- hari setiap manusia. Media sosial terdiri dari satu set aplikasi internet berbasis Web 2.0 yang memungkinkan pengguna untuk membuat dan bertukar informasi (Kaplan \& Haenlein, 2010). secara bertahap mengubah cara hidup tradisional melalui penggunaannya dalam komunikasi dan hiburan, dan 
pengaruhnya sangat kuat pada anakanak muda (Ainin, Naqshbandi, Moghavvemi, \& Jaafar, 2015). Media sosial tidak lagi hanya sebatas komunikasi sosial yang sifatnya sederhana tetapi telah merambah di setiap aspek kehidupan sosial, termasuk budaya, ekonomi bisnis, gaya hidup dan lain sebagainya. Misalnya, media sosial telah menciptakan model pemasaran jaringan baru, transfer budaya tertentu atau bahkan membentuk suatu platform budaya tertentu. Hubungan yang signifikan secara statistik juga diungkapkan antara penggunaan aplikasi seluler belanja online dan media sosial yang telah dilaporkan, dan belanja online sangat bergantung dan berkorelasi dengan media sosial. Para ahli juga menemukan bahwa niat untuk menggunakan media sosial sangat mempengaruhi niat dalam perdagangan sosial, maupun niat menyampaikan kultur tertentu atau bahkan memproduksi suatu bentuk budaya baru tertentu.
Media sosial telah menjadi alat bantu yang penting bagi siswa dalam konteks seperti pengajaran online, diskusi kelompok, komunikasi akademik dan lokakarya online (Moran, Seaman, \& Tinti-Kane, 2011). Terdapat bukti bahwa penggunaan Twitter yang efektif di lembaga pendidikan dipengaruhi oleh partisipasi dan kerjasama publik. Satu studi melaporkan bahwa siswa yang menggunakan Facebook untuk melakukan interaksi terkait kelas dalam bentuk kehadiran sosial, membantu meningkatkan kinerja ujian mereka (Al-Dheleai, Tasir, \& Jumaat, 2020) Media sosial bahkan telah berperan dalam mempengaruhi kesadaran politik masyarakat dan dalam meningkatkan efikasi politik (Pasek, Kenski, Romer, \& Jamieson, 2006).

Dalam dibidang medis, media sosial telah digunakan untuk meningkatkan komunikasi antara perawat dan pasien dan memberikan konsultasi online untuk pasien (Smailhodzic, Hooijsma, Boonstra, \& 
Jurnal Ilmu Budaya, Vol. 18, No. 1 Agustus Tahun 2021

Langley, 2016). Munculnya aplikasi video semakin mendorong perkembangan dan penggunaan media sosial. Komite kesehatan provinsi di Tiongkok telah mulai mengoperasikan akun resmi di TikTok untuk menyebarkan pengetahuan kesehatan masyarakat yang secara signifikan meningkatkan kesadaran kesehatan dasar di Tiongkok (Zhu, Xu, Zhang, Chen, \& Evans, 2019).

TikTok adalah platform internet yang relatif baru dibandingkan dengan platform seperti YouTube dan Facebook. Namun, selama beberapa tahun terakhir perusahaan telah melihat pertumbuhan pesat di seluruh dunia, dengan sekitar 800 juta pengguna aktif secara global saat ini (Singh \& Blase, 2020), Popularitas perusahaan menjadikan platform ini sebagai titik fokus untuk menyebarkan informasi dengan berbagai isu yang populer. Lebih lanjut, para ahli telah menyatakan keprihatinan bahwa penyebaran informasi itu dapat menjadi rumah bagi misinformasi dan disinformasi.
Sebenarnya Misi TikTok adalah "untuk menginspirasi kreativitas dan membawa kegembiraan." Menurut perusahaan, politik bukanlah topik yang dianggap membawa kebahagiaan bagi penggunanya. Akibatnya, perusahaan secara aktif melarang penggunaan layanannya untuk sarana politik. Untuk tujuan ini, pada tahun 2019, perusahaan melarang iklan politik. Larangan tersebut melarang setiap iklan berbayar yang merujuk, mempromosikan, atau menentang.

Lebih lanjut artikel ini akan membahas bagaimana potensi konvergensi budaya dalam platform media sosial TikTok. Adapun teori yang digunakan dalam artikel ini adalah platform dan infrastruktur media social, dan budaya konvergensi. Adapun teori ini akan diuraikan di pembahasan lebih lanjut.

\section{Platformisasi \\ Infrastrukturisasi Media Sosial}


Jurnal Ilmu Budaya, Vol. 18, No. 1 Agustus Tahun 2021

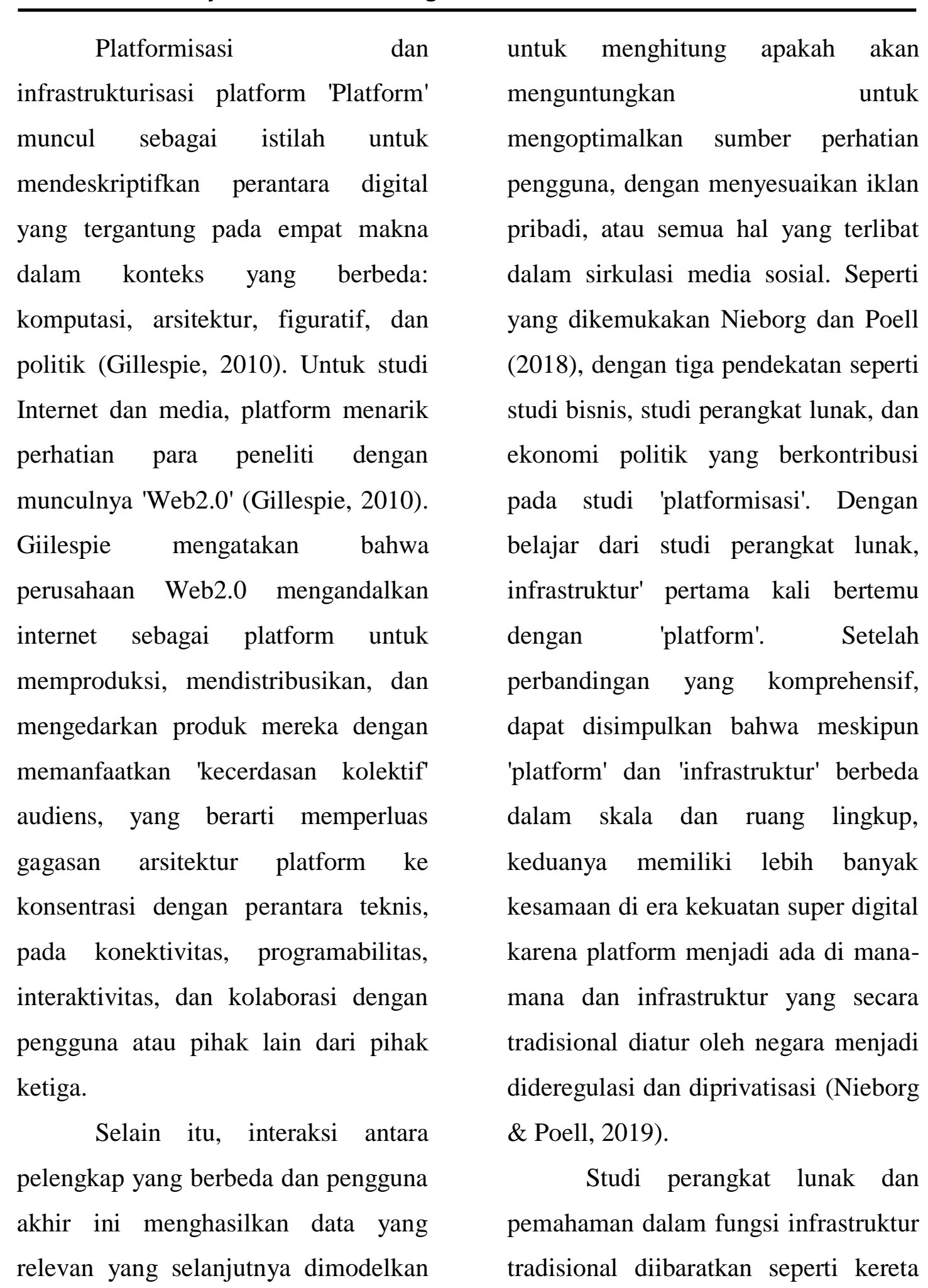


api, sarjana mencurahkan perhatian pada pertanyaan penting tentang platform layanan infrastruktur apa yang memungkinkan untuk melengkapi akses ke sarana sirkulasi untuk konten dan kemudian bagaimana platform menuai keuntungan dari sisi 'menjangkau' dan 'mengunci' para penggunanya didalam media sosial. strategi distribusi digunakan untuk menyelaraskan dengan infrastruktur data platform, dengan demikian akan membentuk sifat teknis untuk mempertahankan kekuatan monopoli platform dan akhirnya tumbuh sebagai penjaga gerbang di dalam media sosial (Kitchen, 2014). Misalnya, melalui messenger, Facebook memiliki berbagai sikap untuk mengoperasikan agenda infrastrukturnya dan dengan demikian mengerahkan pengaruhnya secara global (Nieborg \& Poell, 2019). Hal ini merupakan inisiatif dalam mengatur data terbuka, Facebook sebenarnya membatasi dalam pengembangan dan pengguna aplikasi dengan 'mengunci kedua grup ke dalam lanskap yang ditentukan dan dikendalikan oleh Facebook' (Kitchen, 2014). Sementara upaya dari studi perangkat lunak mengisi kesenjangan antara teknologi platform dan model bisnis, dengan penetrasi platform yang berkelanjutan ke dalam domain publik sosial, hal ini dapat dijelaskan bahwa terdapat implikasi ekonomi politik dalam ekosistem platform yang lebih rumit. Seperti yang dikemukakan oleh Van Dijck (2013), para sarjana harus mempertimbangkan kembali 'sosialitas online' dalam studi media sosial. Platform infrastruktur sudah mulai merambah sektor sosial yang ada seperti transportasi umum, kesehatan, dan pendidikan. Sampai batas tertentu, tidak ada ruang publik di luar platform karena ekosistem semakin berbaur dengan lembaga publik yang ada dan dapat diprediksi semuanya bergantung pada layanan infrastruktur operasional swasta, termasuk mesin pencari, komputasi cloud, analitik data, toko aplikasi, hosting video, dan jejaring sosial (Dijck, 2018).

Oleh karena itu, para ahli telah mengalihkan perhatian mereka dari 
memeriksa keterjangkauan dan teknik arsitektur perantara online ke masalah lintas sektor yang lebih luas dengan bidang lain, seperti platform pendidikan online dan operasi pendidikan publik tradisional secara keseluruhan. Didorong oleh mekanisme algoritmik dan model bisnisnya, platform dengan cepat mengubah proses belajar dan mengajar dan akhirnya memengaruhi kesetaraan pendidikan dalam menyeimbangkan manusia dari konteks sosial ekonomi yang berbeda (Dijck, 2018). Oleh karena itu, 'pergantian infrastruktur' platform tidak hanya tinggal pada penekanan sifat sifat teknik yang fungsinya mirip dengan infrastruktur, tetapi lebih terkait dengan keniscayaan dan keterjeratan platform dalam kehidupan sehari-hari.

Dalam studi yang terbaru dan dinamika industri, 'pergantian infrastruktur' dapat diperluas menjadi pertanyaan berikut: pertama, hubungan kekuatan ekosistem platform. Seperti yang disebutkan Plantin dan Punathambekar (2019) dalam edisi khusus Infrastruktur Media Digital di Media, Budaya dan Masyarakat, 'optik infrastruktur membantu kita melihat bagaimana hubungan kekuasaan antara pemangku kepentingan dan pengguna membentuk jaringan komunikasi seperti uang dibayangkan. Kedua, tata kelola/regulasi platform dalam infrastruktur. Gagasan dalam membangun infrastruktur digital ini juga mengandung asumsi bahwa sejauh mana platform swasta dapat tunduk pada kontrol regulasi karena infrastruktur tradisional telah diatur sedemikian rupa.

Dikarenakan domain ruang pribadi dan ruang publik telah dikaburkan dengan cepat oleh berbagai platform media sosial, siapa yang akan bertanggung jawab atas masalah wabah yang berkelanjutan untuk membangun platform yang lebih akuntabilitas (Dijck, 2018)? Ketiga, wacana platform infrastruktur. Berbagai platform sekarang telah menyesuaikan tujuan pengembangan mereka dan membuat pernyataan sebagai membangun 'infrastruktur 
sosial'. Sebagai contoh, Facebook mengartikulasikan operasi perusahaannya dengan prinsip membaca gratis dan koneksi manusia dan bertujuan untuk membangun komunitas yang mendukung, aman, terinformasi, terlibat secara sipil, dan inklusif; contoh lain seperti perusahaan Alibaba bermaksud untuk membangun platform perdagangan dunia elektronik melalui Belt and Road Initiative dan dengan demikian mewujudkan 'globalisasi inklusif' (Dijck, 2018).

\section{Budaya Konvergensi}

Budaya dapat didefinisikan sebagai manifestasi dari "perilaku yang dipelajari yang terdiri dari pikiran, perasaan dan tindakan" (Hoft, 1996) yang terbentuk di bawah pengaruh lingkungan sosial, biologis, psikologis, ekonomi dan ekologi selama periode waktu yang lama. Selain pengertian tersebut, seperti yang dimaksudkan oleh Hoft, budaya adalah subjek kompleks yang mencakup banyak sekali konsep yang beragam. Pada tahun 1912, Kroeber dan Kluckhohn telah mengidentifikasi 164 definisi budaya, mulai dari "perilaku yang dipelajari" hingga "ide dalam pikiran 'konstruk logis', "sebuah statistik fiksi," dan "mekanisme pertahanan psikis" dan mengklaim bahwa ada lebih dari 300 pengertian. Budaya adalah produk pembelajaran, berubah dari waktu ke waktu dan dari satu tempat ke tempat lain. Perubahan tersebut dipercepat oleh berbagai pertukaran sosial, langsung atau tidak langsung, di antara manusia (Hofstede, Culture's consequences., 1980).

Ketika banyak sekali teknologi baru tersedia dan budaya mengadopsi mereka, hasilnya dapat berupa konvergensi, yaitu ketika suatu budaya menjadi lebih mirip hasilnya, atau divergensi. Ketika budaya mengadopsi teknologi dengan cara yang berbeda yang dalam konteks ini dapat mempertahankan atau bahkan lebih menonjolkan perbedaan mereka.Teori konvergensi, diringkas dengan baik oleh Coughlin (2000), dapat ditelusuri kembali ke abad kedelapan belas. Pada tahun 1960-an, ahli teori konvergensi 
menyarankan bahwa pembangunan ekonomi berarti budaya harus mulai menjadi lebih mirip dalam organisasi sosial, struktur kelas, karakteristik keluarga, dan lain sebagainya. Sementara penelitian menunjukkan bahwa konvergensi tidak berarti tak terelakkan, terutama dalam mode linier sederhana, konsep yang tepat dan tetap dengan cara yang berguna untuk melihat dampak perubahan pada budaya.

Pada dekade saat ini, internet telah membawa revolusi dalam teknologi informasi, yang mempengaruhi banyak aspek kehidupan pribadi, profesional dan sosial bagi mereka yang terhubung didalam suatu platform media sosial. Dari tempat sumbernya, di Amerika Serikat, Internet telah menyebar dengan cepat dalam dekade terakhir dan sekarang dapat diakses di seluruh dunia (walaupun tidak untuk kebanyakan orang di dunia). Internet mengubah cara kita berbisnis, memperoleh pendidikan dan mempelajari keterampilan lain, mengumpulkan informasi, menabung dan berinvestasi, membayar tagihan, mendengarkan musik, menonton film, membeli dan menjual barang, bertukar salam dan berkomunikasi dengan orang lain, mengekspresikan pandangan, berpartisipasi dalam debat dan dihibur.

Perubahan ini cenderung mempengaruhi budaya. Tetapi apakah semua budaya dipengaruhi dengan cara yang sama, yang mengarah pada homogenitas budaya yang lebih besar (yaitu konvergensi)? Apakah Internet merupakan "kawasan budaya virtual", seperti yang disarankan oleh Johnston dan Johal (1999)? Atau apakah kelompok budaya yang berbeda mengadopsi teknologi informasi khusus ini dengan cara yang berbeda sesuai dengan budaya mereka (yaitu divergensi)? muncul efek globalisasi pada budaya. Hipotesis ini dibahas secara lebih rinci oleh Webber (1969), Yang (1986),dan Ronen (1986). Satu hipotesis, konvergensi, menunjukkan bahwa budaya akan menjadi lebih mirip ketika mereka memodernisasi 
Jurnal Ilmu Budaya, Vol. 18, No. 1 Agustus Tahun 2021

karena mereka harus melewati "pola perkembangan yang relatif tetap" (Johnston \& Johal, 1999). Selain itu, "pertumbuhan pesat teknologi telekomunikasi dan komputasi menghasilkan sebuah implikasi mendalam untuk sebuah kemungkinan konvergensi sosial". Internet dapat memainkan peran kunci dalam proses ini.

Sebaliknya hipotesis divergensi, menunjukkan bahwa budaya cenderung menolak asimilasi dan beradaptasi teknologi dengan cara yang berbeda secara budaya. Lebih jauh lagi, biaya asimilasi teknologi bisa sangat besar, membuat budaya tidak dapat berpartisipasi pada tingkat yang sama bahkan jika banyak manusia ingin melakukannya.

Salah satu kesulitan dengan teori konvergensi adalah menentukan di mana mencarinya. Misalnya, Coughlin (2000) mengidentifikasi industrialisasi (termasuk alat produksi, mobilitas dan diferensiasi pekerjaan, peningkatan penekanan pada pendidikan formal, dan pertumbuhan kota), stratifikasi struktur kelas dan prestise pekerjaan, pola demografi, kehidupan keluarga, pendidikan, dan negara kesejahteraan sebagai bidang yang diminati. Kebanyakan penelitian kuantitatif telah cross-sectional, meskipun studi longitudinal tampaknya menjadi lebih tepat (Dijck, 2018)

Sebagian besar penelitian tentang sistem informasi global atau internasional mengambil perspektif divergensi, menunjukkan masalah yang dapat terjadi ketika perbedaan budaya diabaikan. Misalnya, Fernandes (1991) dan Del Galdo dan Nielsen (1996) memberikan panduan tentang desain pengguna. Kedua buku menunjukkan masalah yang terjadi ketika interkasi pengguna yang dirancang untuk satu budaya telah diterapkan ke budaya lain. Baru-baru ini, para peneliti tertarik pada implikasi budaya dari masalah ecommerce global (Davis, 1999).

Tetapi ketika Ein-Dor et al. (1993) menyelidiki pengaruh budaya pada konstruksi sistem informasi 
internasional, mereka menemukan konsistensi yang cukup besar dengan demikian akan mendukung pandangan budaya konvergensi. Ito dan Nakakoji (1996) memberikan contoh konvergensi yang menarik, menunjukkan bagaimana pengolah kata Jepang mengikuti model mesin tik Barat. Johnston dan Johal (1999) menyatakan bahwa internet adalah budaya virtual dan, menggunakan dimensi Hofstede (1980), menyimpulkan bahwa budaya ini berkembang dan menyatu. Marcus dan Gould (2000) meninjau halaman budaya, mendasarkan analisis mereka pada karya terbaru oleh Hofstede (1991). Dapat disimpulkan bahwa budaya, seperti yang diungkapkan oleh dimensi Hofstede, memang mempengaruhi platform media sosial. Dengan demikian, kita juga dapat melihat contoh divergensi ketika budaya mengadaptasi teknologi baru dengan cara yang berbeda untuk memenuhi kebutuhan mereka sendiri.penelitian, menunjukkan bahwa budaya dapat dibedakan melalui lima dimensi utama. Dimensi ini dijelaskan pada Tabel berikut ini :

Web yang dipilih dari berbagai

Tabel 1. Dimensi Budaya Hofstede

\begin{tabular}{|l|l|}
\hline Dimensi & Keterangan \\
\hline $\begin{array}{l}\text { Individualisme- } \\
\text { kolektivisme }\end{array}$ & $\begin{array}{l}\text { Budaya individualistis mengharapkan anggotanya untuk mandiri dan } \\
\text { menjaga diri mereka sendiri. Budaya kolektivitas memiliki kerangka } \\
\text { kerja saling ketergantungan dan kewajiban yang erat. }\end{array}$ \\
\hline Jarak kekuasaan & $\begin{array}{l}\text { Budaya jarak kekuasaan tidak menerima distribusi kekuasaan yang tidak } \\
\text { merata dalam masyarakatnya, Budaya jarak kekuasaan yang rendah akan } \\
\text { berusaha untuk pemerataan dan partisipasinya. }\end{array}$ \\
\hline $\begin{array}{l}\text { Penghindaran } \\
\text { Ketidakpastian }\end{array}$ & $\begin{array}{l}\text { Budaya penghindaran yang kuat berusaha mengendalikan ketidakpastian } \\
\text { dengan aturan dan kode perilaku yang ketat. Budaya penghindaran } \\
\text { ketidakpastian yang lemah tidak dikontrol secara ketat dan } \\
\text { penyimpangan lebih dapat diterima. }\end{array}$ \\
\hline $\begin{array}{l}\text { Maskulinitas- } \\
\text { feminitas }\end{array}$ & $\begin{array}{l}\text { Budaya maskulin menekankan pencapaian, kesuksesan dan ketegasan. } \\
\text { Budaya Feminin menekankan kepedulian, hubungan dekat dan harmoni. }\end{array}$ \\
\hline $\begin{array}{l}\text { Jangka Panjang/ } \\
\text { Jangka Jangka } \\
\text { pendekorientasi }\end{array}$ & $\begin{array}{l}\text { Budaya berorientasi jangka Panjang mempromosikan keluarga, } \\
\text { menghormati orang yang lebih tua, dan perilaku berbudi luhur seperti } \\
\text { kerja keras dan berhemat. Budaya berorientasi jangka pendek } \\
\text { mengembangkan hubungan yang setara, menekankan individu, dan } \\
\text { mempromosikan kreativitas dan aktualisasi diri }\end{array}$ \\
\hline
\end{tabular}

Sumber: adaptasi dari Hunter dan Beck (1997) 
Jurnal Ilmu Budaya, Vol. 18, No. 1 Agustus Tahun 2021

Merujuk pada penelitian awal Hofstede (1980) yang menghasilkan identifikasi empat dimensi budaya:

(1) Jarak kekuasaan; Dimensi Hofstede pertama yang digunakan untuk menganalisis data adalah jarak daya. Dimensi ini berkaitan dengan kesediaan suatu budaya untuk menerima perbedaan kekuasaan atas anggota budaya lainnya. Dengan demikian, budaya jarak kekuasaan yang tinggi cenderung bersedia menerima perbedaan dalam distribusi kekuasaan antar anggota budaya. Namun, budaya jarak kekuasaan yang rendah akan berusaha untuk melakukan pemerataan kekuasaan

(2) individualisme-kolektivisme;

Dalam dimensi ini, Hofstede menyarankan bahwa anggota budaya individualistis akan cenderung mandiri dan akan merasa bertanggung jawab untuk menjaga diri mereka sendiri. Budaya kolektivis, bagaimanapun, akan mencakup anggota yang memelihara serangkaian hubungan interpersonal yang erat dan yang merasakan kewajiban sosial untuk melakukannya. Hubungan dan kewajiban ini paling sering terwujud dalam keluarga besar.

(3) Maskulin feminin; Dimensi ini, menurut Hofstede, berkaitan dengan kualitas, bukan kuantitas, kehidupan. Dengan demikian, budaya maskulin menekankan pada ketegasan dan pencapaian, sedangkan budaya feminin menekankan harmoni dan kepedulian.

(4) penghindaran ketidakpastian; Hofstede menyarankan bahwa budaya akan bervariasi sesuai dengan kesediaan anggota untuk menghadapi ketidakpastian. Dengan demikian, budaya penghindaran ketidakpastian yang kuat akan mengadopsi aturan dan kode perilaku yang ketat untuk mengurangi ketidakpastian yang dihadapi dalam aktivitas sehari- 
Jurnal Ilmu Budaya, Vol. 18, No. 1 Agustus Tahun 2021

hari.Namun, budaya

penghindaran ketidakpastian

yang lemah akan mengadopsi

pendekatan yang kurang

terkontrol.

\section{Mengenal Platform Tik Tok}

$$
\text { Pada September 2016, }
$$

perusahaan China ByteDance merilis

aplikasi pembuatan video sinkronisasi

bibir serupa yang disebut Douyin dan

kemudian meluncurkan TikTok untuk

pasar di luar China. Di bulan November 2017, ByteDance membeli

Musical.ly dan menggabungkannya dengan TikTok pada 2018. Dengan lebih dari 176 juta unduhan pada kuartal ketiga 2019 (Bisnis Aplikasi, 2020), TikTok adalah aplikasi Android kedua yang paling banyak diunduh di seluruh dunia dan aplikasi kelima yang paling banyak diunduh di seluruh dunia dari Apple store.

Meskipun ada perbedaan platform, TikTok tampaknya lebih dekat dengan Vine (platform media sosial) daripada cerita Instagram, Facebook, dan Twitter sebagai tempat untuk kreativitas dan eksperimen. Dalam studi sinematik TikTok, (Bresnick, 2019) menggambarkan aplikasi sebagai taman bermain virtual dan lebih sebagai media kreatif daripada media sosial, menunjukkan bahwa TikTok membebaskan anak muda untuk bermain tanpa mengikuti gaya visual, narasi, dan budaya online di masa lalu. Ada opsi dan efek audiovisual yang mengundang kepercayaan dengan pengguna yang menggunakan aplikasi sebagai pelarian dari kenyataan.

Dalam menggulir konten di TikTok, pada saat yang sama, ada konten yang berlawanan dengan yang dibuat-buat, tidak ada peningkatan audiovisual, hanya orang-orang yang berbicara ke kamera dari mobil mereka atau dimanapun mereka berada. Ada kekacauan kreatif yang ada di aplikasi yang semakin diperdalam oleh elemen ketidakpastian. Pada saat kita membuka aplikasi, pada saat satu gesekan ke atas, sulit untuk mengantisipasi apa yang akan muncul, dan beberapa gesekan dapat 
memunculkan berbagai konten yang menakjubkan yang dapat digambarkan sebagai sesuatu hal yang tulus, ironis, ngeri, sehat, menyinggung, berpurapura, otentik, konyol, membingungkan, dan segala sesuatu di dalamnya. Kekacauan ini telah digambarkan sebagai fitur, bukan bug dari dunia online dan merupakan contoh dari pola pikir budaya yang dikenal sebagai metamodernisme (Bresnick, 2019).

TikTok didorong oleh algoritma, yang membuatnya unik dari aplikasi media sosial lain yang dimodelkan di sekitar pengikutnya. Video TikTok dari pengguna pada awalnya yang tidak memiliki pengikut dapat dengan cepat mendapatkan pemirsa seperti yang muncul di fitur umpan pengguna lain. Tolentino (2019) menggambarkan TikTok sebagai "jejaring sosial yang tidak ada hubungannya dengan jejaring sosial seseorang. Sebuah pabrik meme yang sangat besar, memadatkan dunia menjadi butiran viralitas dan mengeluarkan butiran itu sampai Anda kenyang atau tertidur (Tolentino, 2019). Pelet viralitas itu kemudian dengan mudah dibagikan di luar platform di platform media sosial lain yang membawa lebih banyak pengguna ke aplikasi.

TikTok tersedia untuk diunduh di toko aplikasi Apple, Android, dan Amazon. Meskipun ada cara untuk melihat video dan tombol untuk mengunggah video, tidak ada fungsi pencarian, dan banyak fitur yang tampaknya terbatas. Dimungkinkan untuk melihat dan mencari di aplikasi tanpa memiliki akun, tetapi seperti semua aplikasi media sosial, akun diperlukan untuk keterlibatan penuh. Setelah membuat akun, pengguna akan diminta untuk memilih minat mereka dari daftar yang mencakup hewan, komedi, perjalanan, makanan, olahraga, kecantikan dan gaya, seni, permainan, serta sains dan pendidikan. Sebagai aplikasi yang terutama didorong oleh algoritma, bagian ini membantu aplikasi untuk menentukan video mana yang bisa dilihat oleh pengguna. Setelah memilih berminat 
atau melewatkan, ketika tidak disukai, pengguna diperkenalkan ke aplikasi melalui tutorial.

Meskipun aplikasi ini mungkin intuitif untuk beberapa orang, tutorial dapat menghemat waktu dan perjuangan bagi kita yang tidak menemukan interaksi yang intuitif pada awalnya. Tidak seperti aplikasi media sosial seperti Facebook, Instagram, Twitter, dan Tumblr yang menyajikan umpan yang relative lebih mudah, TikTok menyajikan konten satu video pada satu waktu, dan pengguna harus menggesek ke atas untuk video berikutnya. Video pada tampilan akan terus berulang hingga pengguna menggeser ke atas atau mengetuk layar untuk menjeda. Seperti yang diharapkan, menggesek ke bawah akan mengembalikan pengguna ke video yang dilihat sebelumnya. Umpan video default adalah algoritme yang didorong untuk pengguna, tetapi di bagian atas layar, pengguna dapat memilih untuk membatasi umpan video mereka hanya untuk pengguna yang mereka ikuti. Twitter dan Tumblr yang menyajikan umpan untuk menggulir, TikTok menyajikan konten satu video pada satu waktu, dan pengguna harus menggesek ke atas untuk video berikutnya. Video pada tampilan akan terus berulang hingga pengguna menggeser ke atas atau mengetuk layar untuk menjeda. Seperti yang diharapkan, menggesek ke bawah akan mengembalikan pengguna ke video yang dilihat sebelumnya. Umpan video default adalah algoritme yang didorong "Untuk Anda", tetapi di bagian atas layar, pengguna dapat memilih untuk membatasi umpan video mereka hanya untuk pengguna yang mereka ikuti. Twitter dan Tumblr yang menyajikan umpan untuk menggulir, TikTok menyajikan konten satu video pada satu waktu, dan pengguna harus menggesek ke atas untuk video berikutnya. Video pada tampilan akan terus berulang hingga pengguna menggeser ke atas atau mengetuk layar untuk menjeda. Seperti yang diharapkan, menggesek ke bawah akan mengembalikan pengguna ke video yang dilihat sebelumnya. 
Ikon pada layar video termasuk avatar pengguna, hati, gelembung obrolan, panah berbagi, dan lingkaran berputar dengan not musik yang keluar darinya. Mengklik avatar pengguna membawa Anda ke halaman profil pengguna. Halaman profil pengguna mirip dengan Instagram, menampilkan pengikut dan mendaftar orang-orang yang diikuti pengguna. Semua video pengguna juga muncul di halaman ini. Jika pengguna telah membuat mereka bisa memilih menjadi publik, semua video di platform yang mereka sukai dapat dilihat di sini. Ikon menu (tiga titik) akan menampilkan opsi untuk membagikan profil pengguna, melaporkan profil, mengaktifkan notifikasi, memblokir pengguna, dan mengirim pesan langsung kepada pengguna. Pengguna dapat diikuti dengan mengklik tombol ikuti pada halaman profil. Ikon hati yang dapat ditekan untuk menyukai video, dan jumlah suka muncul di bawah hati. Ikon gelembung obrolan menunjukkan jumlah komentar, dan mengkliknya akan memunculkan halaman komentar tersebut. Komentar juga dapat disukai, dan muncul dalam urutan berdasarkan jumlah suka, dengan komentar yang paling disukai muncul di bagian atas. Mirip dengan aplikasi media sosial lainnya, pengguna dapat ditandai di komentar dengan menggunakan @. Ikon panah menampilkan beberapa opsi berbagi (aplikasi perpesanan, aplikasi media sosial yang tersedia) bersama dengan item tindakan lain untuk video.

Di sinilah video dapat dilaporkan atau di mana pengguna lain dapat memberi sinyal bahwa mereka tidak tertarik dengan video tersebut (mungkin membantu menginformasikan algoritma). Jika pembuat konten telah mengizinkannya, video juga dapat diunduh dari opsi bagikan. Jika pembuat konten telah mengaktifkan opsi, pemirsa dapat bereaksi atau berduet. Bereaksi pada dasarnya adalah menjawab video yang dilihat dengan video milik sendiri. Video asli muncul dalam sebuah kotak kecil di layar, memungkinkan penonton untuk melihat baik yang asli 
maupun reaksinya. Opsi duet membagi layar untuk kinerja simultan, terkoordinasi, atau perbandingan. Ini tampaknya menjadi salah satu fitur unik dari aplikasi yang telah membantunya mendapatkan popularitasnya, mendorong pengguna untuk membuat video mereka sendiri bersama para influencer dan bintang TikTok. Opsi tambahan termasuk menyimpan dan membagikan sebagian video sebagai gif dan menambahkan video ke fitur favorit.

Salah satu fitur unik TikTok sebagai aplikasi untuk sinkronisasi bibir adalah setiap video dipasangkan dengan soundtrack. Lingkaran berputar dengan not musik muncul di setiap video, dan mengkliknya akan menampilkan lebih banyak informasi tentang suara bersama dengan semua video yang menggunakan suara ini. Sebagian besar konten di TikTok adalah pengguna yang membuat ulang video atau suara asli, sehingga suara yang lebih populer akan memiliki ratusan video yang menyertainya. Faktanya, TikTok asal mulanya merupakan Jalan Kota Tua oleh Lil Nas X dan telah dicatat sebagai contoh pertama meme viral TikTok yang menjadi hit chart-topping (Tolentino, 2019). Dari halaman suara, ada opsi untuk gunakan suara ini bagi pengguna untuk membuat video mereka sendiri dengan soundtrack itu. Suara juga dapat ditandai untuk dianggap sebagai sesuatu yang difavoritkan untuk disimpan agar dapat digunakan, dibagikan, atau didengar di masa mendatang. Suara juga dapat dibagikan atau dilaporkan dari halaman ini. Situs media sosial tidak akan berguna tanpa tagar(\#), dan TikTok tidak terkecuali. Tagar muncul di layar video bersama dengan nama pengguna dan dapat diklik untuk menemukan lebih banyak video dengan tagar yang sama. Ikon di sepanjang bagian bawah adalah beranda, temukan, buat video, pesan, dan halaman profil. Temukan menampilkan tagar yang sedang tren dan menyediakan bilah pencarian untuk mencari tagar, video, suara, dan pengguna. 
Ada banyak fitur pilihan dalam platform TikTok, termasuk mengunggah suara atau gambar, filter dan stiker serta kemampuan untuk memanipulasi kecepatan soundtrack dan video. Kemampuan untuk bekerja dengan kecepatan inilah yang telah menarik banyak pengguna ke aplikasi, menyediakan banyak cara untuk pengguna lebih kreatif.

Semua aplikasi media sosial saat ini menghadapi tantangan dalam menangani ujaran kebencian dan menjaga keamanan pengguna dari ancaman, pelecehan, dan bahaya. Tak terkecuali TikTok. Komunitas status terdapat pedoman jangan memposting, membagikan, atau mengirim konten apa pun yang memicu kebencian terhadap sekelompok orang berdasarkan ras, etnis, agama, kebangsaan, budaya, disabilitas, orientasi seksual, jenis kelamin, identitas gender, usia, atau diskriminasi lainnya. Akun dapat dilaporkan dalam aplikasi di beberapa tempat berbeda, dan pelanggaran dapat mengakibatkan penghapusan konten atau hilangnya akun. Namun, seperti yang terlihat di platform lain seperti Twitter, Instagram, dan Facebook, ini pedoman komunitas tidak sering menjadi penghalang, dan reaksi terhadap pelaporan pelanggaran dapat digambarkan sebagai tidak konsisten. Laporan dan investigasi telah memberikan bukti akun sayap kanan dan neo-nazi menggunakan TikTok untuk propaganda dan radikalisasi (Bresnick, 2019). Ketika kekhawatiran ini dibawa ke TikTok, mereka menjawab bahwa mereka akan menambahkan lebih banyak moderator konten (Cox, 2018) (Tolentino, 2019). Pencarian cepat pada beberapa istilah kebencian yang ditandai dalam laporan menghasilkan pesan "frasa ini mungkin terkait dengan perilaku kebencian," dan tidak ada hasil yang dapat diberikan, jadi tampaknya TikTok telah membahas beberapa di antaranya.

Ada juga kekhawatiran bahwa sementara ujaran kebencian dan pelecehan seksual ada di platform yang memiliki dampak yang luar 
biasa, pidato lain sedang disensor. Satu akun pengguna diblokir setelah mereka memposting video yang berbicara tentang Muslim di China misalnya (Zhong, 2019) tentu saja hal ini mempengaruhi budaya; ada kekhawatiran yang tidak berdasar tentang apakah moderator konten menyembunyikan video tentang protes Hong Kong (Zhong, 2019)dan kekhawatiran tentang kebijakan moderasi khususnya seputar konten politik (Dijck, 2018). Kebijakan moderasi lainnya juga dipertanyakan. Kebijakan yang mengklaim telah diberlakukan untuk mengatasi cyberbullying sebenarnya menekan video pengguna yang dinonaktifkan, mencegahnya menjadi viral (Zhong, 2019).

TikTok, seperti semua platform media sosial, juga dapat menjadi platform untuk menyebarkan informasi yang salah, konspirasi, dan tipuan, dan ada kekhawatiran tentang kemampuan untuk melawannya di dalam platform (Dijck, 2018). Perusahaan mengatakan bahwa mereka prihatin tentang hal ini dan menyatakan bahwa mereka memiliki beberapa hal yang dapat perbaiki: kebijakan, memastikan platform mereka memiliki moderator ahli yang tahu cara mendefinisikan jenis konten itu, apa itu informasi yang salah, dan memastikan memiliki teknologi untuk memindai hal-hal seperti penyalahgunaan yang terkoordinasi (Lorenz, 2019b).

Apa yang membuat TikTok unik adalah kekhawatiran yang meningkat dengan privasi dan keamanan data. Tentu saja, seseorang harus melihat dengan cermat semua platform media sosial dalam hal privasi dan penggunaan data pribadi, tetapi banyak makalah terbaru tentang TikTok berfokus pada masalah khusus untuk aplikasi tersebut.

\section{Simpulan}

Pada dekade saat ini, internet telah membawa revolusi dalam teknologi informasi, yang mempengaruhi banyak aspek kehidupan pribadi, profesional dan sosia. Tentu saja diperuntukkan bagi 
Jurnal Ilmu Budaya, Vol. 18, No. 1 Agustus Tahun 2021

mereka yang terhubung didalam suatu platform apakah itu media social namanya. Perubahan yang sangat cepat ini cenderung berpotensi mempengaruhi budaya. Dan tentu saja terdapat budaya yang dipengaruhi dengan cara yang sama, yang mengarah pada homogenitas budaya yang lebih besar yaitu konvergensi budaya dalam metamodernisme.

Potensi aplikasi media sosial apa pun harus dipertimbangkan dengan kemungkinan adanya jebakan yang mempengaruhi budaya atau bahkan ada misi bahwa banyak platform membentuk suatu budaya baru berdasarkan apa yang pengguna ingin tampilkan. Sementara banyak sekali aplikasi media sosial yang bisa merusak tatanan budaya lama atau sifatnya tradisional dan juga berangsur-angsur mentransferkan suatu budaya yang mudah diterima.

TikTok telah terbukti menjadi perhatian besar dalam hal tranformasi budaya, dimulai dari menjalankan platform yang sangat mudah sampai pada tahap berbagai macam kepentingan yang menyusup didalamnya. Muatan muatan budaya yang lebih mudah untuk diikuti oleh khususnya dikalangan anak muda. Tentu saja hal ini melintasi batas daerah tempat budaya mereka anut. Dan hal ini membuktikan bahwa memang dunia dikendalikan oleh Algoritma didalam platform.

\section{Daftar Pustaka}

Ainin, S. M., Naqshbandi, M., Moghavvemi, S., \& Jaafar, N. I. (2015). Facebook, socialization and academic performance. Computers and Education, 64-73.

Al-Dheleai, Y. M., Tasir, Z., \& Jumaat, N. F. (2020). Depicting Students' Social Presence on Social Networking Site in Course-Related Interaction. Original Research, SAGE Open, 1-8.

Bresnick, E. (2019). Intensified play: cinematic study of TikTok mobile app. Media and Cinematic, 125-134.

Dijck, J. V. (2018). The Platform Society. New York: Oxford University Press. 
Jurnal Ilmu Budaya, Vol. 18, No. 1 Agustus Tahun 2021

Gillespie, T. (2010). The Politics of Platform. New Media \& Society, 347-364.

Hofstede, G. (1980). Culture's consequences. Beverly Hills: CA : SAGE.

Hofstede, G. (1991). Cultures and organizations : software of the mind. London: McGraw-Hill New York.

Ainin, S. M., Naqshbandi, M., Moghavvemi, S., \& Jaafar, N. I. (2015). Facebook, socialization and academic performance. Computers and Education, 64-73.

Al-Dheleai, Y. M., Tasir, Z., \& Jumaat, N. F. (2020). Depicting Students' Social Presence on Social Networking Site in Course-Related Interaction. Original Research, SAGE Open, 1-8.

Bresnick, E. (2019). Intensified play: cinematic study of TikTok mobile app. Media and Cinematic, 125-134.

Dijck, J. V. (2018). The Platform Society. New York: Oxford University Press.

Gillespie, T. (2010). The Politics of Platform. New Media \& Society, 347-364.
Hofstede, G. (1980). Culture's consequences. Beverly Hills: CA : SAGE.

Hofstede, G. (1991). Cultures and organizations : software of the mind. London: McGraw-Hill New York.

Johnston, K., \& Johal, P. (1999). The Internet as a "virtual cultural region": are extant cultural classification schemes appropriate? Internet Research, 105-26.

Kaplan, A. M., \& Haenlein, M. (2010). Users of the world, Unite! The Challenges and opportunities of sosial Media. Business Horizons, 59-68.

Kitchen, R. (2014). The data revolution: Big Data, open and Data Infrastructures and their Consequences. London: SAGE.

Marcus, A., \& Gould, E. W. (2000). Croscurrents: Cultural Dimensions and Global Web Users-Interface Design. Interactions, 32-46.

Moran, M., Seaman, J., \& Tinti-Kane, H. (2011). Teaching, Learning, and Sharing: How Today's Higher Education Faculty Use Social Media. Georgia: Pearson.

Nieborg, D., \& Poell, T. (2019). The Plaformization of cultural production: theorizing the 
Jurnal Ilmu Budaya, Vol. 18, No. 1 Agustus Tahun 2021

contingent cultural comodity. New Media \& Society, 42754292.

Pasek, J., Kenski, K., Romer, D., \& Jamieson, K. H. (2006). America's Youth and Community Engagement: How Use of Mass Media Is Related to Civic Activity and Political Awareness in 14- to 22-YearOlds. Communication Research, 115-135.

Singh, S., \& Blase, M. (2020). How Internet Platforms Are Addressing Election and Voter Suppression-related Misinformation and Disinfoemation. US: New America, JSTOR.

Smailhodzic, E., Hooijsma, W., Boonstra, A., \& Langley, D. J. (2016). Social media use in healthcare: A systematic review of effects on patients and on their relationship with healthcare professionals. BMS

Health Services Research, 442.

Tolentino, J. (2019, January I Agustus 2021). Hoe TikTok holds our attention The New Yorker. Retrieved from www. Newyorker.com: www. Newyorker.com

Zhong, R. (2019, Agustus 1 Agustus 2021). TikTok reverses ban on teen who slammed China's Muslim crackdown. Retrieved from New York Times: www.nytimes.com

Zhu, C. Z., Xu, X., Zhang, W., Chen, J. C., \& Evans, R. (2019). How Health Communication via Tik Tok Makes a Difference: A Content Analysis of Tik Tok Accounts Run by Chinese Provincial Health Committees. Chinese Journal of Communication, 66-83. 